29. Sin D, Svenson L, Cowie R, Man SF. Can universal access to health care eliminate health inequities between children of poor and nonpoor families? A case study of childhood asthma in Alberta. Chest 2003;124(1):51-56.

30. Offord D, Boyle M, Jones B. Psychiatric disorder and poor school performance among welfare children in Ontario. Can J Psychiatry 1987;32:518-25.

31. Lipman E, Offord D. Disadvantaged Children in the Canadian Guide to Clinical Preventive Health Care, The Canadian Task Force on the Periodic Health Examination. Ottawa: Minister of Supply and Services Canada. 1994 Cat No. H21-117/1994E: 356-68.

32. Braun-Fahrlander C, Riedler J, Herz U, Eder W, Waser M, Grize L, et al. Environmental exposure to endotoxin and its relation to asthma in school-age children. $N$ Engl JMed 2002;347(12):869-77.

33. Riedler J, Braun-Fahrlander C, Waltraud E. Exposure to farming in early life and development of asthma and allergy: A cross-sectional survey. Lancet 2001;358:112933.

34. Celedon J, Wright R, Litonjua A, Sredl D, Ryan L, Weiss S, Gold D. Day care attendance in early life, maternal history of asthma, and asthma at the age of 6 years. Am J Respiratory Critical Care Med 2003;167:1239-43.

35. Kramer U, Heinrich J, Wjst M, Wichmann H-E. Age of entry to day nursery and allergy in later childhood. Lancet 1999;353:450-54.

36. McConnell R, Berhane K, Gilliland F, Islam T, Gauderman W, London S, et al. Indoor risk factors for asthma in a prospective study of adolescents. Epidemiology 2002;13:288-95.

37. Gunnbjornsdottir M, Norback D, Plaschke P, Norrman E, Bjornsson E, Janson C. The relationship between indicators of building dampness and respiratory health in young Swedish adults. Respiratory Medicine 2003;97(4):302-7.

38. Rauh V, Chew G, Garfinkel R. Deteriorated housing contributes to high cockroach allergen levels in innercity households. Environ Health Perspect 2002;110 (suppl 2):323-27.

39. Gent J, Triche E, Holford T, Belanger K, Bracken M, Beckett W, et al. Association of low-level ozone and fine particles with respiratory symptoms in children with asthma. JAMA 2003;290(14):1859-67.

40. Raizenne M, Dales R, Burnett R. Air pollution exposures and children's health. Can J Public Health 1998;89(Suppl 1):S43-S48.

Received: February 16, 2004

Accepted: July 30, 2004

\section{Book Review/Recension}

\author{
Safe Drinking Water, Lessons from Recent Outbreaks in Affluent Nations \\ Steve E. Hrudey, Elizabeth J. Hrudey. London, England: IWA Publishing, 2004; \\ $514 p p$, US\$145
}

Steve and Elizabeth Hrudey are experts on the assessment and management of environmental health risks. They have assembled an excellent synopsis of drinking water outbreaks in wealthier countries.

The first three chapters of this book cover a variety of topics related to the supply of safe drinking water, including a review of the first-known drinking water outbreak reported by John Snow in London in 1854, a summary of waterborne microorganisms responsible for drinking water outbreaks, and a description of the source to tap concept to safe drinking water.

Chapter 4 is the core of the book, summarizing some 70 outbreak case studies from 14 countries spanning more than 30 years. Each case study details the drinking water system, the responsible microorganism (when known), and the circumstances leading to the outbreak. This information will be valuable to drinking water purveyors to help ensure that the same situations do not occur in their systems.

The next two chapters detail the recurring theme of the book, i.e., the necessity of "converting hindsight into foresight" to avoid future outbreaks. They describe many of the challenges facing the drinking water industry and the limitations encountered when responding to these challenges. The authors present some useful examples from jurisdictions around the world on the shift in the provision of drinking water from being reactive to a more preventive approach based on the concept of source to tap.

The final chapter emphasizes that the microbiological safety of drinking water should be the primary concern and that disinfection should never be compromised to reduce the formation of disinfection by-products. Although the book does not address chemical risks, it does recognize that under certain conditions some chemicals can pose a health risk and should be managed.

There are three take-home messages in this book. First, to avoid future outbreaks, we need to learn lessons from our past mistakes. Second, regardless of treatment technology in place, the skill of the individuals operating the technology is critical to the prevention of outbreaks. Operator training can be the difference between the successful management of a system and a serious outbreak. And third, the source to tap approach is the key to ensuring a continuous supply of safe drinking water.

The information presented in this book will benefit all those involved in the supply of safe drinking water, including plant operators, regulatory bodies, health officials, academics, consultants and many others. The authors have included an extensive list of references for those readers who are interested in exploring this topic further.

[Declaration of Interest: The reviewer provided data and comments to the authors on an early draft of this book.]

Teresa Brooks, MSc

Microbiologist, Microbiological Assessment Section

Water Quality and Health Bureau

Health Canada

Will Robertson

Head, Microbiological Assessment Section

Water Quality and Health Bureau

Health Canada 